\title{
IMPACT OF URBANIZATION ON INFLOWS AND SEDIMENTATION LOAD IN RAWAL LAKE OF PAKISTAN
}

\author{
Muhammad Afzal*, Muhammad Awais, S.M.S. Shah, Sajid Mahmood and Muhammad Kaleem \\ Sarwar
}

\author{
*Centre of Excellence in Water Resources Engineering, University of Engineering and Technology Lahore, Pakistan. \\ "Corresponding author's e-mail: afzelbutt@yahoo.com
}

\begin{abstract}
The presence of water for the livelihood of human beings is inevitable. This study was carried out to perceive the impact of ever increasing urbanization in the catchment area of Rawal Lake on inflows of water and sedimentation. Rawal Lake is constructed on Korang River and supplies water for domestic use to Rawalpindi city and Cantonment Area. The results argue that the population in the last eleven years has increased up to $85 \%$ at a growth rate of $5.7 \%$, while the built up land has increased $9 \%$. On the other hand area under forest area has been decreased up to $10 \%$. As a result of increase in urbanization inflows to the lake have decreased even though there is no major change in rainfall trend and contributed to the amount of suspended sediment in the inflows. The suspended sediment load was found to be varies from 16.45 tons/day to 1045 tones/day during low to high inflow season.
\end{abstract}

Keywords: Urbanization, sediment, inflows, watershed, Rawal lake, Korang river.

\section{INTRODUCTION}

An agro-based country, Pakistan is largely dependent on one of the world's largest contagious Indus Basin Irrigation System (IBIS) for the agriculture (Azmat, 2015). Therefore, in order to meet with the needs of food, fiber and for other purposes due to increase of population and immense pressure on the water resources system every country is trying to do its best for water resources storage, regulation and management. The variations in climate and catchment characteristics largely effecting the inflows of the rivers (Azmat et al., 2016; Shakoor et al., 2015). However, water resources are largely affected by several natural hazards due change in climate conditions such as sedimentation, earthquakes and floods etc. It has been documented that world's 13 large rivers carrying 5.8 billion tons of sediments to the reservoirs every year (Nasir et al., 2006). Poor management of erosion prone areas has resulted in flooding and rapid filling of water reservoirs (Nasir et al., 2006). Kahlown et al. (2002) stated that the Indus and its tributaries carries about $0.35 \mathrm{MAF}$ of sediment load annually, almost $60 \%$ ( $0.2 \mathrm{MAF}$ ) of which deposits in the reservoirs, canals and irrigation fields.

Islamabad and Rawalpindi are two very important and twin cities of Pakistan. Rawalpindi city is one of the largest populated cities of province Punjab having population of about more than 1.41 million, according to 1998 census. Catchment area of the Rawal Lake is reducing very rapidly due to urbanization during last few decades which leads to poor quality and quantity of inflows to the lake. Indeed, an increase in sediment load caused by the urbanization into the reservoir due to the exposure of bare lands which further approaches to the destruction of natural land cover. Rawal Dam is a major source of drinking water to Rawalpindi, however, the dam capacity and water quality is diminishing with time therefore, water is getting polluted and also caused sedimentation. The rate of urban growth can seriously challenge the integrity of rivers and streams. Number of studies (Moehansyah et al., 2002; Thothong et al., 2011; Huang et al., 2015; Bashir et al., 2013) have carried out to analyze the impact of land use change on inflows and sedimentation of the basin prevailing to the urbanization. These studies suggest that hydrological changes in urban watersheds can most often be attributed to the modification of stream characteristics which govern discharge, stream chemistry, stream/ floodplain interactions and channel morphology. As a result, urbanization is thought to cause reduced base inflows, increased frequency and magnitude of peak discharges, increased sediment loads, reduction in channel and floodplain complexity and impaired water quality (Dunne and Leopold, 1978). Therefore, the aim of this study was to analyze the inflow variations due to urbanization and its implications on sedimentation of the Rawal Dam.

\section{MATERIALS AND METHODS}

Rawal Lake has been constructed across Korang River, a tributary of the Soan River basin. The reservoir comprises of the following three zones such as main lake, Korang River and Noorpur triple arm. The Korang enters the lake from Murree hill side and the creek formed by it is termed as a Korang arm. Noorpur Shah Nullah enters from the north side in the middle of the lake along with two hill torrents which 
termed as the Noorpur triple arm. The remaining is the main body of the lake (Fig. 1).

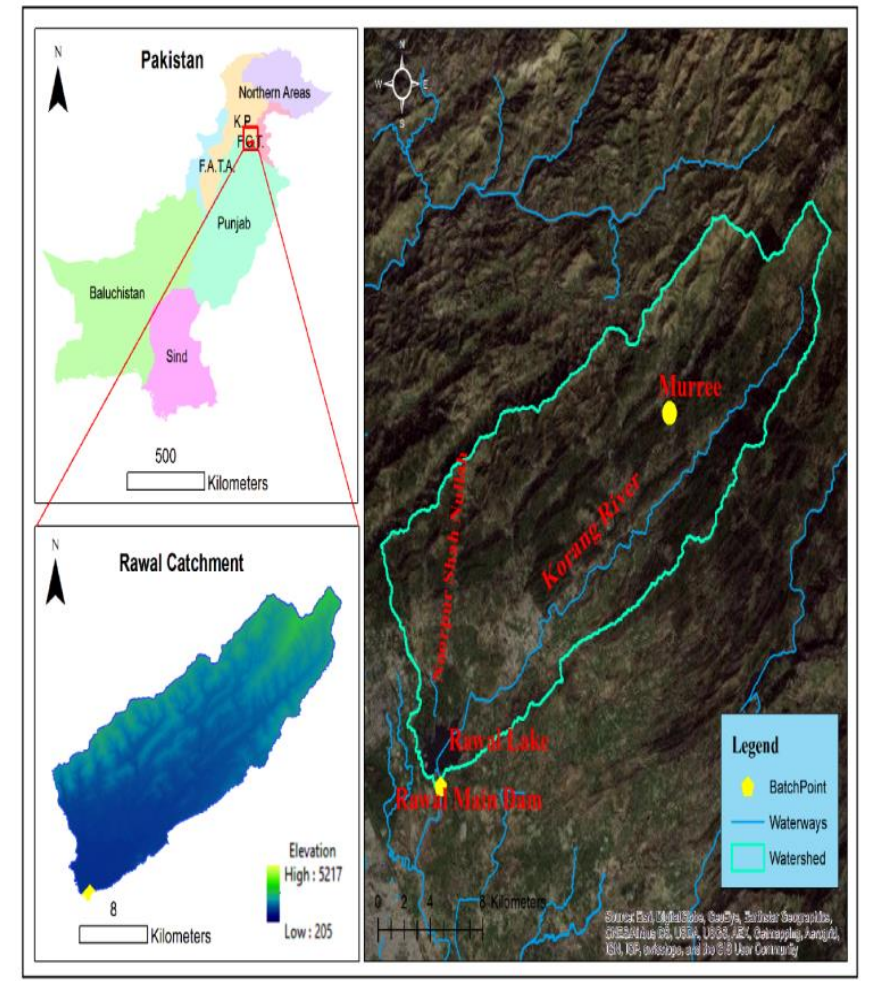

Figure 1. Location of study area.

Land use data: Land use data of the Rawal Lake catchment was collected from Revenue Department, Government of Punjab (RDP) and Capital Development Authority (CDA), Islamabad, Pakistan.

Population data: The population data Rawal Lake catchment was obtained from Population and Census Organization Statistics Division, Government of Pakistan and Pakistan Environmental Protection Agency (Ministry of Environment), Islamabad, Pakistan. As the census conducted by the government of Pakistan was in year 1998 so the data regarding population was also of 1998 . To obtain the latest updated and correct rate of growth of population data, estimation was done using the compound interest formula derived from geometric mean which gives the correct rate of the growth of population as given below:

$$
P_{t}=P_{o}(1+r)^{n}
$$

Where; $\mathrm{Pt}=$ Population at time ' $\mathrm{t}$ '; Po $=$ Population data available; $r=$ Growth Rate $(5.70 \%)$ as provided by Pakistan Bureau of Statistics (PBS); $\mathrm{n}=$ No. of years

Inflows and rainfall data: The inflow data at Rawal Dam for 34 years (1975-2009) were collected from Small Dam Organization (SDO) Punjab and rainfall data at Murree, Rawal Dam and Rawalpindi station for 17 years (1992-2009) were collected from Pakistan Meteorological Department (PMD).

Sediment data: To estimate the sedimentation in the reservoir, both types of loads (suspended and bed load) were determined and analyzed, carried by the streams. The silt load carried in suspension can be measured quite easily, however, it is often difficult to access the bed load. By keeping in view the scope of the study, only suspended sediment load was considered for this study.

To interpret and analyze the sediment input rate in Rawal Lake, physical measurements and sample collection was performed. The samples of suspended sediment were taken from the tail of Main Korang River at different reaches during low flow and high flow season and their mean value was taken for analysis purpose. The hand sampler was used to collect the suspended sediment samples. The sampler was fabricated locally having the length of 9 inches and $2 \mathrm{~kg}$ weight. The sample containers (round bottles) were also fabricated locally having the storage volume $430 \mathrm{ml}$ with a nozzle of $1 / 4$ inches diameter. The concentration (ppm by weight) of collected samples was computed in the laboratory by using the following relation:

$$
C=\frac{W_{s}}{W_{w}} \times 10^{6}
$$

Where, $\mathrm{C}=$ Concentration (ppm by weight); Ws= Weight of sediment (difference between weight of sediment with filter and weight of filter); $\mathrm{Ww}=$ Weight of water in sediment mixture; (difference between weight of bottle with sample and weight of empty bottle).

\section{RESULTS AND DISCUSSION}

Population data: The trend analysis of average annual precipitation and inflows at Rawal Dam during 1975-2009, are presented in Figures 2 and 3, which depicts a decreasing trend in inflows while a consistent trend in precipitation at all three stations. It can be seen that a decreasing trend in inflows was observed during most of the years particularly after 2000, which could be associated with the fact of historical heavy rainfall occurrence during monsoon season changes as stated by Azmat et al. (2015). Moreover, the decreasing inflow trend conversely to the consistent precipitation trend could be justification of large change in land use land cover of the Rawal Catchment which approaches to the decreasing runoff generation due to precipitation losses and sedimentation.

The hydrological data were compared with the population in the catchment area of the Rawal Lake to visualize the impact of population on inflows which indicates that population in the catchment area of the Rawal Lake has increased (85\% of the total) from 60,733 to 112,333 during 1998 and 2009, respectively. On the other hand, the average inflows of last ten years from 1999-2009 has decreased by approximately $44 \%$ as compared to the period from 1988-1998 (Fig. 4). 
The Villages of BharaKahu, Malpur, Bani Gala and Noorpur Shahan are located very close to Rawal Lake vicinity. The estimated population of these villages is about 5,000.Other ten (10) villages are situated in the catchment area of Rawal Lake under the administration of Murree-Kahuta Development Authority. The present numbers of inhabitants in these villages are not exactly known because the latest census data available is only for the year 1998, therefore, the data of 1998 was utilized for estimation of approximate population during 2009, in these villages by using statistical technique. The detail of population data of these villages is given in Table 1.

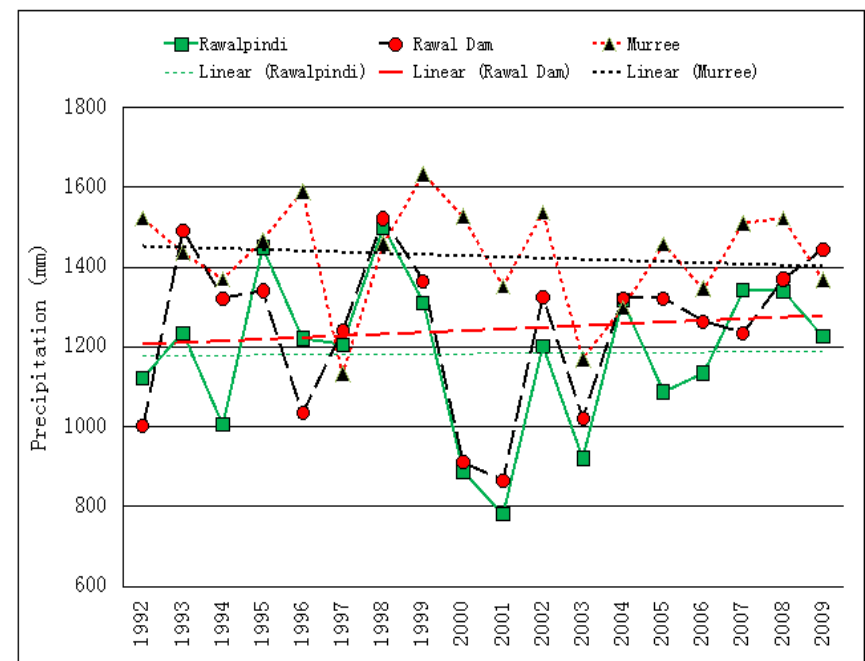

Figure 2. Trend analysis of average annual precipitation at Rawal Dam, Murree and Rawalpindi climate stations during 1993 to 2009.

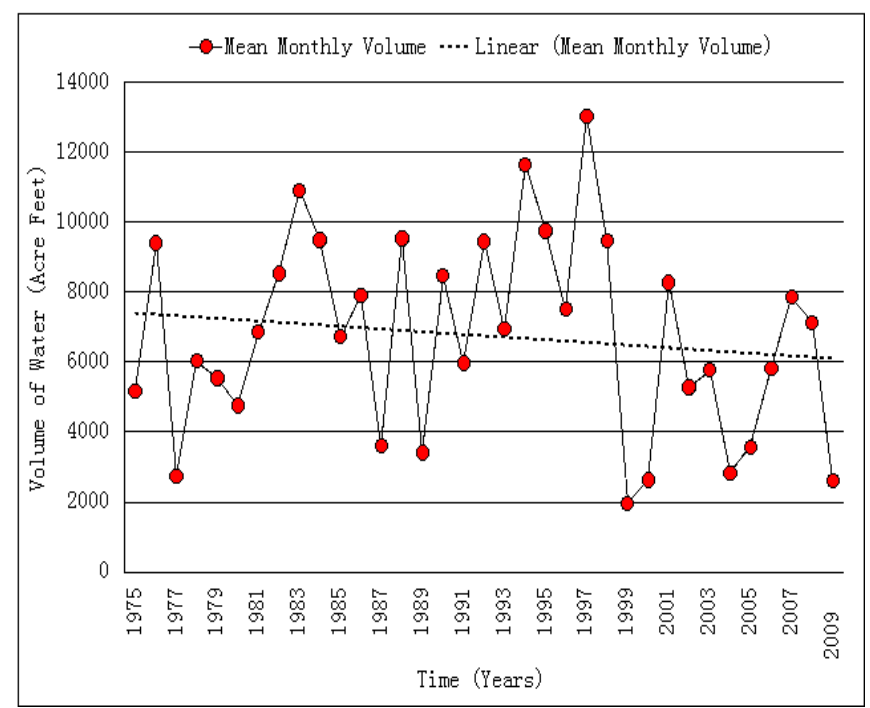

Figure 3. Trend analysis of average annual inflows at Rawal Dam during 1975 to 2009.

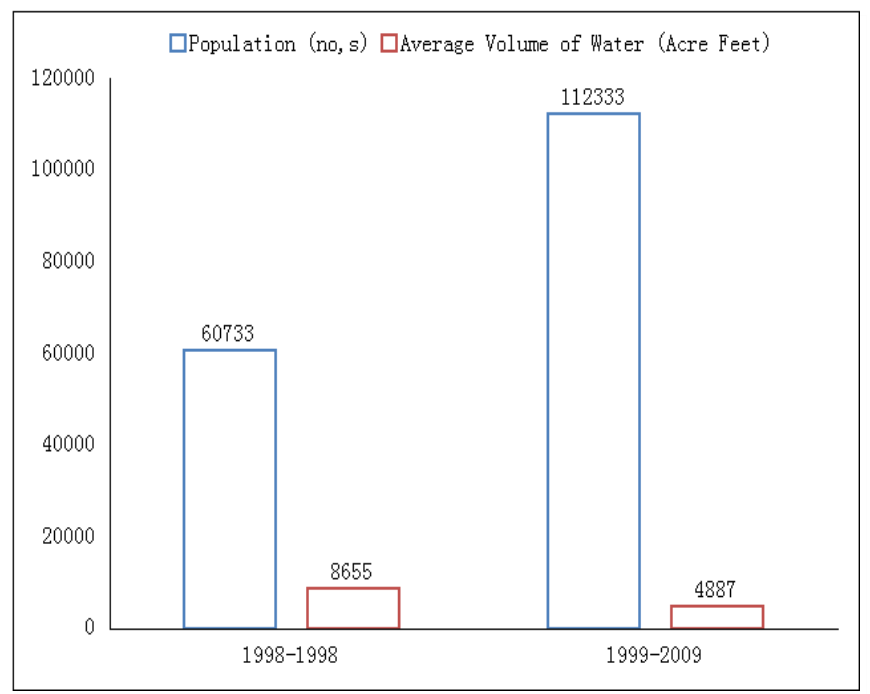

Figure 4. Comparison of population and volume of water received at Rawal Lake.

Table 1. Population status in Rawal Lake catchment.

\begin{tabular}{llrc}
\hline $\begin{array}{l}\text { Sr. } \\
\text { No. }\end{array}$ & Village & $\begin{array}{c}\text { Population } \\
\mathbf{1 9 9 8}\end{array}$ & $\begin{array}{c}\text { Population 2009 } \\
\text { (Estimated) }\end{array}$ \\
\hline 1 & KotHathial & 27,258 & 50,417 \\
2 & (BharaKahu) & 3,743 & 6,923 \\
3 & Malpur & 8,075 & 14,936 \\
4 & Nambor & 5,205 & 9,627 \\
5 & SambiTajal & 3,876 & 7,169 \\
6 & Treet & 2,137 & 3,953 \\
7 & Salgran & 1,536 & 2,841 \\
8 & Manga & 5,149 & 9,524 \\
9 & Karlot & 717 & 1,326 \\
10 & Salkhitar & 1,086 & 2,009 \\
11 & Kathar & 995 & 1,840 \\
12 & Jumma & 956 & 1,768 \\
\hline & Total & 60,733 & 112,333 \\
\hline
\end{tabular}

Comparison of land use type and inflows: Table 2 indicates that from year 1998-2009 the urbanization has increased i.e. the built up area has increased, area under forests has decreased while there is also little change in agricultural activities as well as range land. On the other hand the trend of inflows from 1998-2009 has decreased. The reduction in inflows can be due to change in land use pattern because as the population increases the requirement for built up land which includes housing plus commercial area also increases. For which area under forest as well as range land is converted in to build up land, thereby minimizing the natural green land cover and producing more barren land which ultimately results in less rainfall and hence reduces the inflows. 
Afzal, Awais, Shah, Mahmood \& Sarwar

Table 3. Sediment input analysis during low inflow season of Korang River at Rawal Dam.

\begin{tabular}{lcccccccc}
\hline $\begin{array}{c}\text { Sr } \\
\text { No }\end{array}$ & $\begin{array}{c}\text { Sample } \\
\text { No }\end{array}$ & $\begin{array}{c}\text { Sampling } \\
\text { Date }\end{array}$ & $\begin{array}{c}\text { Sample total weight } \\
\text { (Bottle + Liquid) (g) }\end{array}$ & $\begin{array}{c}\text { Bottle } \\
\text { weight (g) }\end{array}$ & $\begin{array}{c}\text { Liquid with } \\
\text { sediment (g) }\end{array}$ & $\begin{array}{c}\text { Sediment } \\
\text { with filter (g) }\end{array}$ & $\begin{array}{c}\text { Filter } \\
\text { weight (g) }\end{array}$ & $\begin{array}{c}\text { Sediment } \\
(\mathbf{g})\end{array}$ \\
\hline 1 & A1 & $25-05-09$ & 843.6 & 491.8 & 351.8 & 2.30 & 2.00 & 0.30 \\
2 & A2 & -do- & 788.2 & 55.0 & 333.2 & 1.66 & 1.33 & 0.33 \\
3 & A3 & -do- & 834.0 & 472.1 & 361.9 & 1.99 & 1.70 & 0.29 \\
4 & A4 & -do- & 805.5 & 479.7 & 307.8 & 1.99 & 1.70 & 0.29 \\
5 & A5 & -do- & 798.6 & 497.8 & 301.0 & 2.11 & 1.30 & 0.31 \\
\hline
\end{tabular}

Table 4. Sediment input analysis during high inflow season of Korang River at Rawal Dam.

\begin{tabular}{lccccccccc}
\hline $\begin{array}{l}\text { Sr } \\
\text { No }\end{array}$ & Source & $\begin{array}{c}\text { Sampling } \\
\text { Date }\end{array}$ & $\begin{array}{c}\text { Sample } \\
\text { No }\end{array}$ & $\begin{array}{c}\text { Sample total weight } \\
\text { (Bottle + Liquid) }(\mathbf{g})\end{array}$ & $\begin{array}{c}\text { Bottle } \\
\text { weight (g) }\end{array}$ & $\begin{array}{c}\text { Liquid with } \\
\text { sediment (g) }\end{array}$ & $\begin{array}{c}\text { Sediment } \\
\text { with filter(g) }\end{array}$ & $\begin{array}{c}\text { Filter } \\
\text { weight (g) }\end{array}$ & $\begin{array}{c}\text { Sediment } \\
(\mathbf{g})\end{array}$ \\
\hline 1 & Korang & $20-08-09$ & D1 & 803.5 & 417.9 & 385.6 & 2.00 & 1.30 & 0.70 \\
& River & & & & & & & & \\
2 & -Do- & -Do- & D2 & 815.6 & 420.6 & 395.0 & 2.03 & 1.35 & 0.68 \\
3 & -Do- & -Do- & D3 & 850.1 & 478.5 & 371.6 & 2.06 & 1.35 & 0.71 \\
4 & -Do- & -Do- & D4 & 847.8 & 452.0 & 395.8 & 2.04 & 1.30 & 0.74 \\
5 & -Do- & -Do- & D5 & 859.0 & 419.3 & 439.7 & 2.09 & 1.40 & 0.69 \\
\hline
\end{tabular}

Table 2. Land use percentage $(\%)$ in the Rawal Lake catchment.

\begin{tabular}{lcrrr}
\hline $\begin{array}{l}\text { Land use } \\
\text { parameters }\end{array}$ & $\begin{array}{c}\text { Area } \\
\text { (acres) } \\
\mathbf{1 9 9 8}\end{array}$ & $\begin{array}{c}\text { Percen- } \\
\text { tage } \\
(\mathbf{\%})\end{array}$ & $\begin{array}{c}\text { Area } \\
\text { (acres) } \\
\mathbf{2 0 0 9}\end{array}$ & $\begin{array}{c}\text { Percen- } \\
\text { tage } \\
(\mathbf{\%})\end{array}$ \\
\hline Urbanized (Housing + & 9,999 & 14.70 & 15,724 & 23.12 \\
Commercial) & 1,643 & 2.42 & 2,653 & 3.90 \\
Cultivable & 39,338 & 57.85 & 33,101 & 48.68 \\
Forest & 17,020 & 25.03 & 16,522 & 24.30 \\
Range Land & 68,000 & 100.00 & 68,000 & 100.00 \\
\hline Total & & &
\end{tabular}

Sediment analysis: The sediment analysis at the tail of Main Korang River was carried out for both low flow and high flow seasons to have an idea about the amount of sediment coming in to the reservoir. The sampling collection was done in months of May and August to represent both low flows and high flows, respectively. The sampling was carried out with US-DH-48 hand sampler and analyzed in the laboratory. The analysis were carried out for both low and high inflow seasons as calculated below and the results are illustrated in Tables 3 and 4 , respectively.

Low Korang River inflow season at Rawal Dam: The sediment analysis during low flows was performed by using following relationship:

$$
R_{t}=\frac{2 d}{T_{s}}(3)
$$

Where, $\mathrm{Rt}=$ Transit Ratio $(\mathrm{ft} / \mathrm{sec})$ i.e raising and lowering of sampler; $\mathrm{d}=$ depth of stream $(\mathrm{ft})$; Ts $=$ Time to fill the sampler $(\mathrm{sec})$, "Ts" is calculated from table for which first average stream velocity was calculated by float method and against sample volume of $395 \mathrm{ml}$ value of (Ts) was read. The calculated Rt value was found equal to $0.10 \mathrm{ft} / \mathrm{sec}$ which further evaluated from Rt-diagram and noticed that it falls in an acceptable limit by dividing Rt with mean velocity and having known depth of stream. The average value of sediment concentration in the water after laboratory (Center of Excellence in Water Resources Engineering (CEWRE) laboratory) analysis was calculated to be $0.3 \mathrm{~g}$ for Korang River. The concentration of sediment at Korang River was found about $852.7 \mathrm{ppm}$. It should be noted that one $\mathrm{ppm}$ sediment concentration in water is equal to $1 \mathrm{mg} / \mathrm{L}$. Moreover, by using aforementioned relationship, the average load of suspended sediment (tons/day) into the reservoir was found 16.54 tons/day, during the month of May (average of 17 years; 1062 AF), 1998 and 2009 (low inflow season).

High Korang River inflow season at Rawal Dam: The sediment calculation analysis for high inflow season by using same equation (Equation 3) used for low inflow season for high inflow season are given in Table 4 . The Rt value was found $0.12 \mathrm{ft} / \mathrm{sec}$ which further was evaluated with Rtdiagram to check the acceptability by dividing Rt with mean velocity and known depth of the stream. The average value of sediment after laboratory analysis was found as $0.7 \mathrm{~g}$ for Korang River. The concentration on (ppm by weight) using Equation 4 is as follows;

$$
C=\frac{0.7}{385.6 \times 10^{6}}=1818.35 \text { ppm (Korang River) }
$$

Working on the same relationship, average load of suspended sediment (tons/day) into the reservoir was calculated to be 1045.5 tons/day, during the month of August (average of 17 years; 20,427 AF), 1998 and 2009 (high inflow season).

Comparison of sediment analysis: The analysis for the change in sedimentation and inflow volume conducted in this study were compared with the previous analysis conducted by the Dam Investigation Circle of Government of Pakistan (DICGP) in 1958 during the month of May as presented in Figure 5. Figure 5 depicts that monthly volume of water 
during May 1998 (one month)to the Rawal Lake were 578 AF with the sediment load of 241.11 tons/month, while during 2009 monthly volume was recorded as 472 AF with sediment load of 496.2 tons/month. The aforementioned facts shows a significant increase in sediment load with decrease in volume of water received however, a critical point that the sediment load in a month has been increased than volume of water received. This increase in sedimentation could be associated with the rapid urban growth rate which consequently leads to the deforestation and reduction in natural land cover. Such deforestation and land cover change activities ultimately could cause of increase in erosion and sediment load.

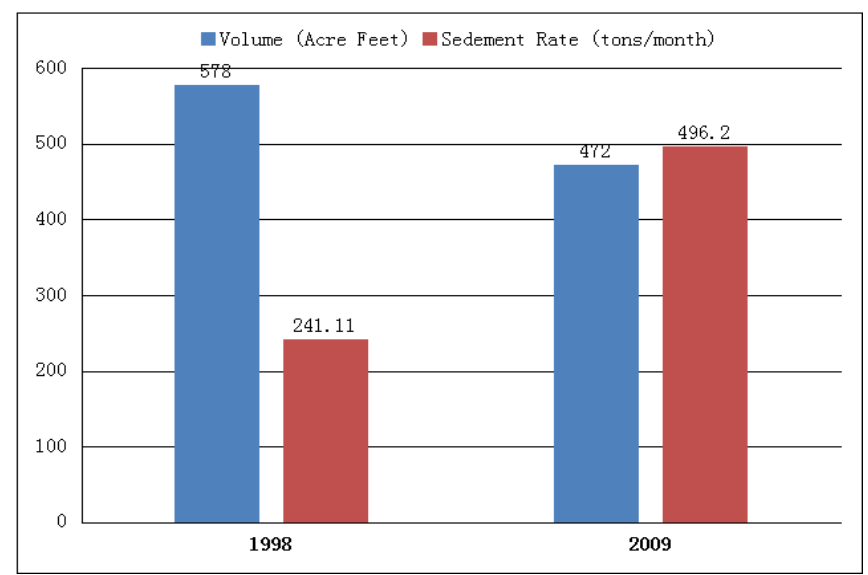

Figure 5. Comparison of sediment rate and inflows to the Rawal Lake.

Conclusions: The Population in the catchment area of Rawal Lake has been grown enormously specially during the last 11 years i.e. 1998-2009. The estimated population results show an increase of $84 \%$ as compared to that of 1998 at a growth rate of $5.75 \%$ per annum. The Land use pattern has changed in the catchment of Rawal Lake during the period 1998-2009 the area under the category of built up land has increased from 14.7 to $23.12 \%$, while area under forest has decreased from 58 to $48 \%$. The average inflows from (1998-2009) have decreased as compared to the average of previous years inflow, the increase in urbanization in the catchment area is a factor of this decrease in inflows. There is no major change in the rainfall in the catchment area but inflows have decreased which proves that inflows have been decreasing due to urbanization. The suspended sediment inflow in the reservoir during low inflow season was 16.54 tons/day. During high inflow season the sediment inflow was increased and it was 1045.5 tons/day.

Recommendations: The proper strategic planning of urban societies much needed in the catchment of Rawal Lake. A number of illegal housing projects and commercial construction activities are underway which are a major source of reduction in inflow volume and deterioration of the water quality as well as producing more sediment load towards the reservoir. Area under forest must be increased which is decreasing day by day and is not only creating environmental problems but also reducing the flows and increasing sediment input rate. A comprehensive compilation of land use data at village level is recommended so that up to date and more reliable figures should be obtained.

\section{REFERENCES}

Azmat, M., F. Laio and D. Poggi. 2015. Estimation of water resources availability and mini-hydro productivity in high-altitude scarcely-gauged watershed. Water Resour. Manage. 29:5037-5054.

Azmat, M. 2015. Water resources availability and hydropower production under current and future climate scenarios: The case of Jhelum River Basin, Pakistan. Ph.D. dissertation, Politecnico di Torino.

Azmat, M., M. Choi, T.W. Kim and U.W. Liaqat. 2016. Hydrological modeling to simulate stream flow under changing climate in a scarcely gauged cryosphere catchment. Environ. Earth Sci. 75:1-16.

Bashir, S., M. Baig, M. Ashraf, M. Anwar, M. Bhalli and S. Munawar. 2013. Risk assessment of soil erosion in Rawal watershed using geoinformatics techniques. Sci. Int. (Lahore) 25:583-588.

Dunne, T. and L.B. Leopold. 1978. Water in environmental planning. W.H. Freeman Co., San Francisco; p.818.

Huang, T.C.C. and K.F.A. Lo. 2015. Effects of land use change on sediment and water yields in Yang Ming Shan National Park, Taiwan. Environments 2:32-42. Doi: 10.3390/environments2010032.

Kahlown, A., A. Majeed and M.A. Bhatti. 2002. Contribution of mountains in Pakistan's water resources status and prospects. Annual Report PCRWR, Islamabad, Pakistan.

Moehansyah, H., B.L. Maheshwari and J. Armstrong. 2002. Impact of land-use changes and sedimentation on the Muhammad Nur Reservoir, South Kalimantan, Indonesia. J. Soils Sediments 2:9-18.

Nasir, A., K. Uchida and M. Ashraf. 2006. Estimation of soil erosion by using RUSLE and GIS for small mountainous watershed in Pakistan. Pak. J. Water Resour. 10:11-21.

Shakoor, A., M. Arshad, A. Bakhsh and R. Ahmed. 2015. GIS based assessment and delineation of groundwater quality zones and its impact on agricultural productivity. Pak. J. Agri. Sci. 52:837-843.

Thothong, W., S. Huon, J.L. Janeau, A. Boonsaner, A. de Rouw, O. Planchon, G. Bardoux and P. Parkpian. 2011. Impact of land use change and rainfall on sediment and carbon accumulation in a water reservoir of North Thailand. Agric. Ecosys. Environ. 140:521-533. DOI: 10.1016/j.agee.2011.02.006. 